\title{
Assessment of Juniper Encroachment With the Use of Satellite Imagery and Geospatial Data
}

\author{
Temuulen Tsagaan Sankey ${ }^{1}$ and Matthew J. Germino ${ }^{2}$ \\ Authors are ${ }^{1}$ Postdoctoral Research Associate, GIS Training and Research Center, Idaho State University, Pocatello, ID 83209, USA; and ${ }^{2}$ Associate \\ Professor, Department of Biological Sciences, Idaho State University, Pocatello, ID 83209, USA.
}

\begin{abstract}
Juniper encroachment into otherwise treeless shrub lands and grasslands is one of the most pronounced environmental changes observed in rangelands of western North America in recent decades. Most studies on juniper change are conducted over small areas, although encroachment is occurring throughout regions. Whether changes in juniper cover can be assessed over large areas with the use of long-term satellite data is an important methodological question. A fundamental challenge in using satellite imagery to determine tree abundance in rangelands is that a mix of trees, sagebrush, and herbaceous cover types can occur within a given image pixel. Our objective was to determine if spectral mixture analysis could be used to estimate changes in Rocky Mountain juniper (Juniperus scopulorum Sarg) and Utah juniper (Juniperus osteosperma [Torr.] Little) cover over $20 \mathrm{yr}$ and 20000 ha in southeast Idaho with the use of Landsat imagery. We also examined the spatial patterns and variation of encroachment within our study area using Geographic Information Systems-based data sets of grazing use, land-cover types, and topography. Juniper cover determined from $15-\mathrm{cm}$-resolution digital aerial orthophotography was used to train and validate juniper presence/absence classification in 1985 and 2005 Landsat images. The two classified images were then compared to detect changes in juniper cover. The estimated rate of juniper encroachment over our study area was $22-30 \%$ between 1985 and 2005, consistent with previous ground-based studies. Moran's I analysis indicated that juniper encroachment pattern was spatially random rather than clustered or uniform. Juniper encroachment was significantly greater in grazed areas $(P=0.02)$, and in particular in grazed shrub land cover type $(P=0.06)$, compared to ungrazed areas. Juniper encroachment was also greater on intermediate slopes (10-35\% slopes) compared to steeper or flatter terrain, and encroachment was somewhat less on north-facing $(P=0.03)$ and more on west-facing $(P=0.02)$ slopes compared to other aspects.
\end{abstract}

\section{Resumen}

La invasión de enebro en áreas de matorrales y pastizales previamente sin árboles es uno de los cambios ambientales más pronunciados observados en los pastizales del oeste de América del Norte en las últimas décadas. Muchos estudios sobre el cambio de enebro son conducidos dentro de pequeñas áreas, aunque la invasión está ocurriendo en todas las regiones. Si los cambios en la cobertura de enebro pueden ser evaluados en grandes áreas utilizando datos de satélite a largo plazo seria una importante cuestión metodológica. Un reto fundamental al utilizar imágenes de satélites para determinar la abundancia de árboles en los pastizales es la mezcla de árboles, arbustos, artemisias y los tipos de cobertura herbáceas que puedan ocurrir dentro un píxel de la imagen. Nuestro objetivo fue determinar si el análisis de mezcla espectral podría utilizarse para estimar los cambios en el enebro de las montañas rocallosas (Juniperus scopulorum Sarg) y el enebro de Utah (Juniperus osteosperma [Torr.] Little) cubriendo más de 20 años y 20000 ha en el sureste de Idaho utilizando imágenes Landsat. Nosotros también examinamos los patrones espaciales y la variación de la invasión dentro de nuestra área de estudio utilizando conjuntos de datos basados en Sistemas De Información Geográficos sobre el uso de pastoreo, los tipos de cobertura de suelos y la topografía. La cobertura de enebro determinada a partir de una foto aérea digital a $15 \mathrm{~cm}$ de resolución fue utilizada para entrenar y validar la clasificación de presencia/ausencia de enebro en las imágenes Landsat del 1985 y 2005. Las dos imágenes clasificadas fueron comparadas luego para detectar cambios en la cobertura de enebro. La tasa de estimación de la invasión de enebro dentro de nuestra área de estudio fue 22-30\% entre 1985 y 2005, consecuente con estudios terrestres previos. El análisis de Moran’s I indicó que el patrón de invasión del enebro fue espacialmente aleatorio en vez de agrupado o individual. La invasión de enebro fue significativamente mayor en las áreas pastadas $(P=0.02) \mathrm{y}$, en particular, en las de cobertura arbustiva pastadas $(P=0.06)$, comparadas a las áreas no pastadas. La invasión de enebro también fue más alta en las pendientes intermedias (10-35\% de inclinación) comparadas con los terrenos más planos o más escarpados, y la invasión fue de alguna manera menos en la vertiente norte $(P=0.03)$ y más en la vertiente oeste $(P=0.02)$ comparados a otros aspectos.

Key Words: change detection, Geographic Information Systems (GIS), grazing, Landsat Thematic Mapper, remote sensing, spatial pattern

Research was funded by Grant NNG05GB05G from the National Aeronautics and Space Administration.

Correspondence: Temuulen Tsagaan Sankey, GIS Training and Research Center, Idaho State University, 921 South 8th Ave, Stop 8104, Pocatello, ID 83209, USA. Email: sankteki@isu.edu

Manuscript received 5 December 2007; manuscript accepted 21 April 2008.

\section{INTRODUCTION}

Juniper encroachment is one of the most prominent changes occurring in the rangelands of western North America (Johnsen 1962; Blackburn and Tueller 1970; Burkhardt and Tisdale 1976; Miller and Rose 1995, 1999; Miller et al. 2000; Wall et 
Table 1. Nonexhaustive summary of previous studies on historical juniper expansion in sagebrush steppe of western North America. In most cases, values were estimated from figures or tables, and converted to the common International System (SI) units. NA indicates not applicable.

\begin{tabular}{|c|c|c|c|c|c|}
\hline Authors, year & Species of juniper & Type of evidence & Temporal extent & Spatial extent & Estimated encroachment rate \\
\hline Blackburn and Tueller 1970 & Juniperus osteosperma & Tree-ring/tree density & $1725-1960$ & $1.4 \mathrm{ha}$ & $0.3-0.6$ trees $\cdot \mathrm{ha}^{-1} \cdot \mathrm{yr}^{-1}$ \\
\hline Burkhardt and Tisdale 1975 & J. occidentalis & Tree-ring/tree density & $1830-1970$ & 1040 ha & Up to 31 trees $\cdot \mathrm{ha}^{-1} \cdot \mathrm{yr}^{-1}$ \\
\hline Young and Evans 1981 & J. occidentalis & Tree-ring/tree density & $1600-1978$ & 1000 ha & Up to $\sim 2$ trees $\cdot \mathrm{ha}^{-1} \cdot \mathrm{yr}^{-1}$ \\
\hline Miller and Rose 1995 & J. occidentalis & Tree-ring/tree density & $1878-1990$ & 8.8 ha over $32 \mathrm{~km}$ & Up to 4 trees $\cdot \mathrm{ha}^{-1} \cdot \mathrm{yr}^{-1}$ \\
\hline Miller and Rose 1999 & & Tree-ring/tree density & $1840-1995$ & 5000 ha & NA \\
\hline Johnson and Miller 2006 & J. occidentalis & Tree-ring/tree density & 1850-2005 & $N A ;<2500$ ha & Up to 6 trees $\cdot \mathrm{ha}^{-1} \cdot \mathrm{yr}^{-1}$ \\
\hline Strand et al. 2006 & & Aerial photography & 1939-1998 & 15 ha & $4.5 \%$ increase in cover per year \\
\hline Weisberg et al. 2007 & J. osteosperma & Aerial photography & $1966-1995$ & 2500 ha & $0.4-1.1 \%$ increase in cover per year \\
\hline \multirow[t]{2}{*}{ This study } & J. osteosperma & Satellite imagery & 1985-2005 & 20000 ha & $0.7-1.5 \%$ increase in cover per year \\
\hline & J. scopularum & & & & \\
\hline
\end{tabular}

al. 2001; Baker and Shinneman 2004). Juniper species are documented to have substantially increased in density and extent throughout their range in recent decades, although juniper cover fluctuated in the West during the Holocene and before the Euro-American settlement (Miller and Wigand 1994). As juniper trees mature and canopies close in encroached areas, understory herbaceous species and sagebrush cover can decrease, resulting in soil exposure and erosion (Miller et al. 2000). Soil erosion and herbaceous and shrub cover decline can continue for substantial periods of time because of the longevity of junipers in the absence of fire (Waichler et al. 2001). Intensive land treatments, such as prescribed burning, are now regularly performed to reduce juniper cover where the encroachment is perceived to decrease rangeland forage value or increase fire hazard.

Juniper encroachment has been attributed to climate variability and fire suppression (Miller and Wigand 1994), and variation in encroachment rates has been associated with differences in land cover types (Chambers et al. 1999) and topographic positions (Miller et al. 2000; Weisberg et al. 2007). Interactions among these factors can lead to complex spatial patterns of encroachment, particularly when examined at small spatial scales and in the field (Weisberg et al. 2007). Much of the previously documented juniper encroachment has occurred in shrub steppe communities (Miller and Wigand 1994; Weisberg et al. 2007). Juniper seedlings often establish under sagebrush canopy, as shrubs provide better soil moisture and protection from direct sunlight (Gottfried 1992; Miller and Rose 1995). It has been suggested that livestock grazing might promote juniper establishment by dispersing seeds, reducing competition from herbaceous forage species, and increasing shrub species that provide safe sites for juniper to establish (Gottfried 1992; Miller and Wigand 1994). However, we found no explicit statistical tests of the relationship between long-term grazing effects and increased juniper cover (Table 1).

Most evidence for juniper encroachment is provided by dendrochronological, demographic, or aerial photograph studies that cover relatively small spatial extent (Table 1). However, most land-use decisions and management activities are impacted by regional-scale changes and the associated regional-level policies. Assessment of juniper change over large areas is needed to guide regional policy and land-use management. An important research question is whether changes in juniper cover over large areas and their relationship to grazing, resident land cover types, and topography can be assessed with the use of moderate-resolution Landsat Thematic Mapper imagery and Geographic Information Systems (GIS) data sets. Pixels in Landsat imagery are $900 \mathrm{~m}^{2}(30 \times 30 \mathrm{~m})$ in size and thus frequently have a mix of vegetation cover types, especially in the hilly rangelands of southeast Idaho where juniper trees are dispersed amongst herbaceous and sagebrush cover types during the encroachment process. This mix of cover types within pixels poses a fundamental challenge in classifying pixels, because the spectral characteristics of the mixed pixels do not represent any single land cover type (Lillesand and Kiefer 2000). Spectral mixture analysis techniques have been developed to allow estimates of how much of a pixel is comprised by different land cover types (Adams et al. 1986; Small 2004; Xiao and Moody 2005). Spectral mixture analysis is most suited when there are a limited number of land cover types and when the spectral properties of these cover types can be assumed to be relatively constant. Spectral mixture analysis characterizes the spectral signatures in the imagery as a mix of the land cover types in each pixel, where each cover type is known as a separate "endmember" (Rencz 1999). Once "pure" endmembers (i.e., pure pixels of each cover type) are determined within imagery, endmember fractions or abundance of each cover type within each pixel can be estimated as a linear mixture (Rencz 1999). Spectral unmixing of Landsat imagery has previously been used to map other tree species and to estimate tree fractions within pixels (Chen et al. 2004; Small and Lu 2006).

We studied juniper (Juniperus scopulorum Sarg and J. osteosperma [Torr.] Little) encroachment of the last $20 \mathrm{yr}$ in southeast Idaho with the use of Landsat satellite imagery and spectral mixture analysis. Our objectives were 1) to determine if spectral mixture analysis could be used with Landsat imagery to detect and quantify changes in juniper cover over $20 \mathrm{yr}$ and across 20000 ha and 2) to examine how juniper changes vary due to livestock grazing, resident land cover types, and topographic positions by combining maps of juniper change derived from Landsat imagery with GIS data sets. Juniper encroachment rates could be further complicated by issues such as distance to nearest juniper stand or dispersal limitation, and so we also determined whether juniper encroachment patterns were clustered, random, or uniform. Our choice of Landsat imagery was based on its accessibility, moderate spatial resolution $(30 \times 30 \mathrm{~m})$ compared to other types of satellite 


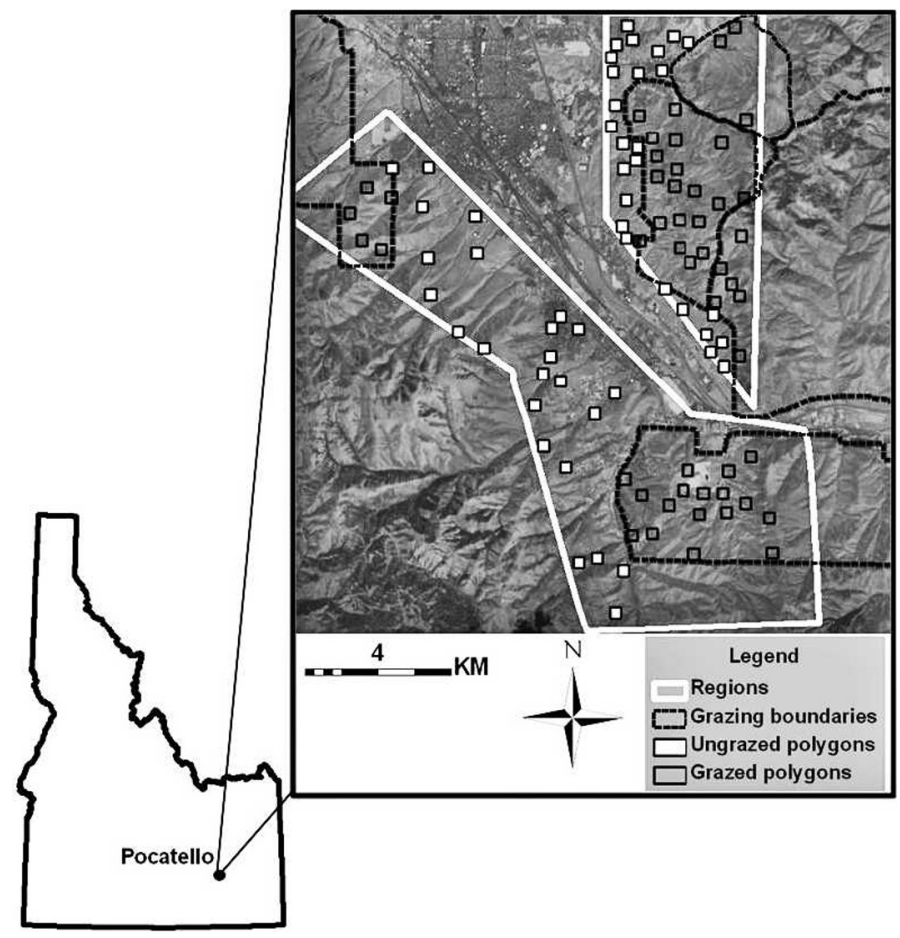

Figure 1. The study regions, grazing boundaries, and the 100 randomly generated sample polygons in the Pocatello area of southeastern Idaho.

data (e.g., MODIS and AVHRR), and global coverage every 16 -d period in seven spectral bands. We chose two Landsat image scenes for juniper change detection: one from August 1985 and another from August 2005. Annual seasonal drought tends to prevail in August in southeast Idaho. The greenness of sagebrush communities is lowest at this time of the year, due to ephemeral leaf drop in sagebrush and senescence of herbaceous species and other shrubs (Bilbrough and Richards 1993; Kremer and Running 1993). We expected this time period to allow more prominent detection of evergreen juniper in the sagebrush-steppe rangeland ecosystem.

\section{METHODS}

\section{Study-Site Description}

Two regions of interest across a total area of $\sim 200 \mathrm{~km}^{2}$ (lat $42^{\circ} 53^{\prime} 18^{\prime \prime} \mathrm{N}$, long $112^{\circ} 28^{\prime} 37^{\prime \prime} \mathrm{E}$ ) were selected for this study, one south of Pocatello and the other west of Pocatello (Fig. 1). The eastern region included Chinese Peak and Camelback Mountain, and the southwestern region included Kinport Peak and Gibson Mountain. Both regions consist of hilly and mountainous topography ranging in elevation from 1400 to $1850 \mathrm{~m}$. Slope ranged between 0 and 45 degrees (in percent) in both regions, and aspect varied between 140 (southwest) and 310 (northwest) degrees in the eastern region and 280 (northwest) through north to 170 degrees (southeast) in the southwest region. A majority of the area is public land managed by the Bureau of Land Management (BLM) and US Forest Service (approximately $40 \%$ and 50\%, respectively); the rest includes private land $(\sim 10 \%)$. The soils are coarse-silty, mixed, frigid Calcic Haploxerolls (Ririe series; US Department of Agriculture [USDA] Natural Resources Conservation Service 1997). Average annual precipitation in Pocatello is $325 \mathrm{~mm}$.

Common plant species are Rocky Mountain juniper ( $J$. scopulorum Sarg), Utah juniper (J. osteosperma [Torr.] Little), big sagebrush (Artemisia tridentata Nutt. spp.), "three-tip" sagebrush (Artemisia tripartita Rydb), grey rabbitbrush (Chrysothamnus nauseosus [Pall.] Britt.), green rabbitbrush (Chrysothamnus viscidoflorus (Hook.) Nutt.), bulbous bluegrass (Poa bulbosa L.), thickspike wheatgrass (Elymus lanceolatus), needle-and-thread grass (Stipa comata Trin. \& Rupr.), cheatgrass (Bromus tectorum L.), and tapertip hawksbeard (Crepis acuminata Nutt.; Ratzlaff and Anderson 1995).

The two regions included grazed areas dispersed throughout ungrazed areas. The grazed areas (five allotments) are managed by the BLM (Fig. 1) and have been used in spring-summer seasons over the last $20 \mathrm{yr}$. Our review of the BLM grazing records and discussions with BLM Range Conservationists revealed that grazing regimes in these areas have been relatively constant during the study time period. The grazed areas vary between 1466-5321 ha in size and 0.01-0.24 animal unit months per hectare in grazing intensity.

\section{Landsat Imagery and Juniper Classification}

We used one Landsat 5 Thematic Mapper satellite image subset from 2 August 1985 and one Landsat 5 Thematic Mapper satellite image subset from 13 August 2005. Both images (Path 039, Row 030) were corrected for atmospheric effects with the use of Idrisi's ATMOSC module (based on Chavez's [1996] $\cos [t]$ model) and projected in Universal Transverse Mercator Zone 12 North, North American Datum 1983 projection and datum. Digital color aerial orthophotography with a $15-\mathrm{cm}$ resolution from August 2004 (USDA National Agricultural Imagery Program 2004) was used for training and validation of Landsat image classification. The 1985 Landsat image was coregistered to the 2005 Landsat image with the use of 30 ground control points (root-mean-squared error $=0.07$ ).

The Matched Filtering Spectral Mixture Analysis technique was used to classify juniper in the Landsat imagery (ENVI Version 4.3, ITT Industries Inc., 2006, Boulder, CO). The Matched Filtering Spectral Unmixing approach detects a userdefined target cover type in the imagery, while suppressing the spectral signatures of other cover types. The classification training requires identification of pure pixels of the cover class of interest. In our case, the target cover type of interest was juniper. The other cover types to be suppressed largely included bare ground, sagebrush, and herbaceous cover, as well as their mix. With the use of $15-\mathrm{cm}$-resolution aerial photography, we selected in each Landsat image 10 pure juniper pixels (approximately 85 trees per pixel) and 10 other pure pixels that clearly had no juniper, but sagebrush and herbaceous cover and their mix. The two Landsat images were trained and classified separately, and fractions of juniper endmember were estimated in both images. Pure pixels were spectrally distinct, similarly in both Landsat images (Fig. 2).

With the use of the estimated juniper fractions in each image, juniper presence and absence was classified in each pixel to produce a binary map of juniper presence and absence for each image date. During this process, a spectral threshold was set between 0 and 1 to decide on juniper absence and presence and 


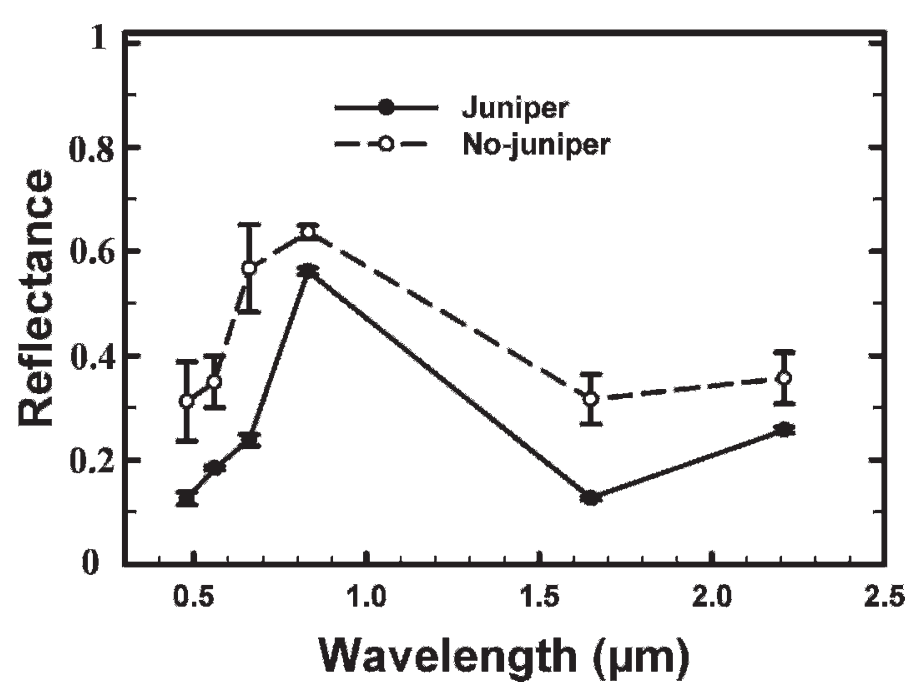

Figure 2. Mean ( $\pm \mathrm{SE})$ spectral reflectance of the "pure" pixels with $100 \%$ juniper cover $(N=10)$ and $0 \%$ juniper cover $(N=10)$ in the Landsat images.

thereby optimize the classification accuracy. To determine the appropriate threshold, we assessed the accuracy of multiple classification models beginning with a nominal threshold value of 0.0 and incrementally increasing the threshold by 0.05 units until increases in threshold no longer improved accuracy. The resulting threshold value was 0.3 . The accuracy of each 2005 juniper classification model was assessed with 65 randomly selected pixels (random points generated by Hawth's tools, ESRI $^{\circledR}{ }^{\text {ArcMap }}{ }^{\text {TM }} 9.1$ software, 1999-2006; ESRI Inc., Redlands, CA) having a range of juniper cover of $0-100 \%$. The pixels were visually estimated in the aerial photograph in $30 \times 30 \mathrm{~m}$ windows to correspond with the 2005 Landsat pixels. The accuracy of each 1985 juniper classification model was assessed with 65 randomly selected pixels having either $0 \%$ or $>50 \%$ cover of large juniper trees $(>2 \mathrm{~m}$ in canopy diameter). There were no high-resolution aerial photographs available for 1985 , so we assumed that $30 \times 30 \mathrm{~m}$ windows having high values of juniper percent cover in the 2004 photographs likely had juniper presence in 1985. Similarly, windows with no juniper in 2004 or trunk skeletons or history of juniper-excluding events between 1985 and 2005 were assumed to have juniper absence in 1985. Our assumptions were supported by local familiarity with this region and the slow growth rates of juniper.

\section{Change Detection}

A postclassification image-differencing method (Lillesand and Kiefer 2000) was used to compare the 1985 and 2005 binary maps and to detect pixels with newly established junipers, where junipers were absent in the earlier date. This allowed us to examine the overall juniper cover increase both in the extent and density across the study area over the 20 -yr period. In addition, we compared the estimated abundances of juniper within each pixel between the two unmixed Landsat images to provide additional information on pixel-level juniper density changes from 1985 to 2005. However, pixel-level juniper fraction estimates were not quantitatively assessed for classification accuracy and were, therefore, not used in further analysis. Only the juniper change map resulting from the comparison of the two binary maps was used in the statistical analysis.

\section{GIS Data Sets}

We created GIS-derived independent variables of grazing, land cover types, and topography with the use of ArcMap 9.1 software. Digital maps of fires and grazed area boundaries were acquired from the BLM (Weber and BLM Pocatello Field Office 2006). A thematic map of land cover types generated by the Idaho GAP Analysis project for the Pocatello area was used. This map included 15 different land cover types in our study area $(70 \%$ overall accuracy) and had a spatial resolution of $30 \mathrm{~m}$ and minimum mapping unit of 2 ha. We performed an independent accuracy assessment of our own within our study area and considered the accuracy of this map acceptable $(75 \%$ overall accuracy). To further improve the accuracy, we combined the 15 land cover types into four classes at the next coarser level of thematic classification. For example, all shrub cover types (i.e., big sagebrush, low sagebrush, and bitterbrush) were grouped into a single cover type of shrub land. The resulting four land cover types included grassland, shrub land, riparian, and urban land (a very small area of housing development outside of the city of Pocatello, as the city was intentionally excluded from our study area). A US Geological Survey digital elevation model (DEM) of 26.8-m resolution was used to derive topographic aspect (in degrees) and slope (in percent).

\section{Statistical Analyses}

We examined the spatial pattern of juniper encroachment within each region with the use of Moran's I to determine if juniper encroachment was clustered, random, or uniform across the landscape. Moran's I index was estimated with the use of the juniper change map and Euclidian distance method with inverse distance relationship in ArcMap 9.1 software. A $Z$-score was also estimated to determine the statistical significance of the estimated $I$. Moran's $I$ values close to -1 indicate a uniform pattern, whereas values close to 1 indicate a clustered pattern. Moran's $I$ values close to 0 indicate a random pattern (O'Sullivan and Unwin 2003).

The relationship between juniper change and landscape factors was examined by analysis of variance (ANOVA; SPSS 14.0 for Windows, 2005). The units of replication were randomly located polygons that each had 100 pixels (a square area of $90000 \mathrm{~m}^{2}$ ). There were 100 replicate polygons, and they were distributed evenly between grazed and ungrazed areas (Fig. 1), with 85 polygons in shrub land, 8 in grassland, and the remaining 7 in riparian and urban areas. The response variable was the number and percent of pixels in the random polygons classified as having new juniper presence in 2005 compared to the 1985 classified image. Data were square-root transformed to meet assumptions of normality. A one-way ANOVA was used to compare juniper increase in grazed and ungrazed polygons. A separate two-factor ANOVA was used to assess whether the grazing effect varied among shrub land and grassland (these were two levels of the second factor, resident land cover), with pairwise post hoc comparisons to examine the interactive effects of grazing and land cover types. 
Table 2. Classification accuracy of juniper presence and absence in 1985 and 2005 Landsat images.

\begin{tabular}{|c|c|c|c|c|c|c|c|}
\hline \multirow[b]{2}{*}{ Image year } & \multirow[b]{2}{*}{ Classification data } & \multicolumn{2}{|c|}{ Training data } & \multirow{2}{*}{$\begin{array}{l}\text { Row } \\
\text { total }\end{array}$} & \multirow{2}{*}{$\begin{array}{c}\text { User's } \\
\text { accuracy }\end{array}$} & \multirow{2}{*}{$\begin{array}{c}\text { Producer's } \\
\text { accuracy }\end{array}$} & \multirow{2}{*}{$\begin{array}{c}\text { Overall } \\
\text { accuracy }\end{array}$} \\
\hline & & Juniper presence & Juniper absence & & & & \\
\hline \multirow[t]{3}{*}{2005} & Juniper presence & 33 & 3 & 36 & $91 \%$ & $94 \%$ & $92 \%$ \\
\hline & Juniper absence & 2 & 27 & 29 & $93 \%$ & $90 \%$ & \\
\hline & Column total & 35 & 30 & & & & \\
\hline \multirow[t]{3}{*}{1985} & Juniper presence & 33 & 11 & 44 & $75 \%$ & $94 \%$ & $80 \%$ \\
\hline & Juniper absence & 2 & 19 & 21 & $90 \%$ & $63 \%$ & \\
\hline & Column total & 35 & 30 & & & & \\
\hline
\end{tabular}

Multiple regression was used to assess the interactive effects of topography and grazing on juniper increase. The topographic aspect and slope associated with each pixel within each random polygon were extracted from the DEM and grouped into four categorical classes of aspect $\left(315-45^{\circ}, 45-\right.$ $135^{\circ}, 135-225^{\circ}$, and $225-315^{\circ}$ ) and three categories of slope $(0-10 \%, 10-35 \%$, and $>35 \%)$ within each polygon. The number of pixels showing new juniper presence from 1985 to 2005 in each polygon was modeled as a response to grazing (grazed or ungrazed), aspect (four classes), and slope (three classes).

\section{RESULTS}

The spectral properties associated with juniper were distinct compared to other cover types. Differences in spectral properties between juniper and the surrounding land cover types were particularly evident at wavelengths longer than $0.6 \mu \mathrm{m}$ in Bands 3, 4, 5, and 7 (Fig. 2). The overall accuracy was $92 \%$ in the 2005 Landsat imagery and $80 \%$ in the 1985 Landsat imagery. Although the spectral signatures of endmembers were similar between the two images, the 1985 image classification had lower user's and producer's accuracies than the 2005 image classification (Table 2), which likely impacted the juniper change estimates.

Over the study period, the number of pixels with new juniper presence from 1985 to 2005 increased $29.7 \%$ in the eastern region and $21.6 \%$ in the southwestern region. Juniper cover per pixel (in all pixels, not just the random polygons) increased $16.6 \%$ in the eastern region and $14.2 \%$ in the southwestern region. The estimated Moran's $I$ was 0.04 with a $Z$ score of 772.3 for the eastern region $(P=0.01)$ and 0.03 with a $Z$ score of 1160 for the southwestern region $(P=0.03)$, indicating that juniper encroachment occurred in a random pattern, but not in a localized clustering or in an even distribution of trees in both regions.

The percentage increase between 1985 and 2005 in pixels of the random polygons having new juniper presence was significantly greater in grazed compared to ungrazed areas, over all land cover and topographic variation $(28.2 \% \pm 17.9$ $\mathrm{SD}$ and $22.5 \% \pm 13.6 \mathrm{SD}$, respectively, $\left.\mathrm{F}_{1,99}=5.31, P=0.02\right)$. There was a marginally significant interaction of grazing and land cover types $\left(\mathrm{F}_{2,99}=2.8, P=0.06\right.$; Fig. 3$)$. Post hoc comparisons indicated that ungrazed grassland had $11.1 \%$ greater juniper increase than ungrazed shrub land $(P<0.0001)$, and grazed shrub land had $9.5 \%$ greater juniper increase compared to ungrazed shrub land ( $P=0.06$; Fig. 3$)$.
The regression model indicated grazing and topography significantly affected juniper change between 1985 and 2005 $\left(P<0.000\right.$ and adjusted $\left.R^{2}=0.81\right)$. Grazing, medium slope class $(10-35 \%)$, and northerly and westerly aspects were significant predictor variables $(P=0.04,0.001,0.03$, and 0.02 , respectively). Medium slope class had $5.6 \%$ and $4.4 \%$ greater juniper increase compared to the flatter and steeper slope classes, respectively (Fig. 4a). Northerly aspects had a somewhat lower rate of juniper increase than other aspects, and westerly slopes had a slightly greater rate of juniper increase (Fig. 4b).

\section{DISCUSSION}

The application of Landsat imagery in classifying and detecting changes in sparsely distributed juniper cover was successful. The spectral mixture analysis allowed accurate detection of juniper presence and absence, especially in the 2005 image classification, which then generated realistic temporal change

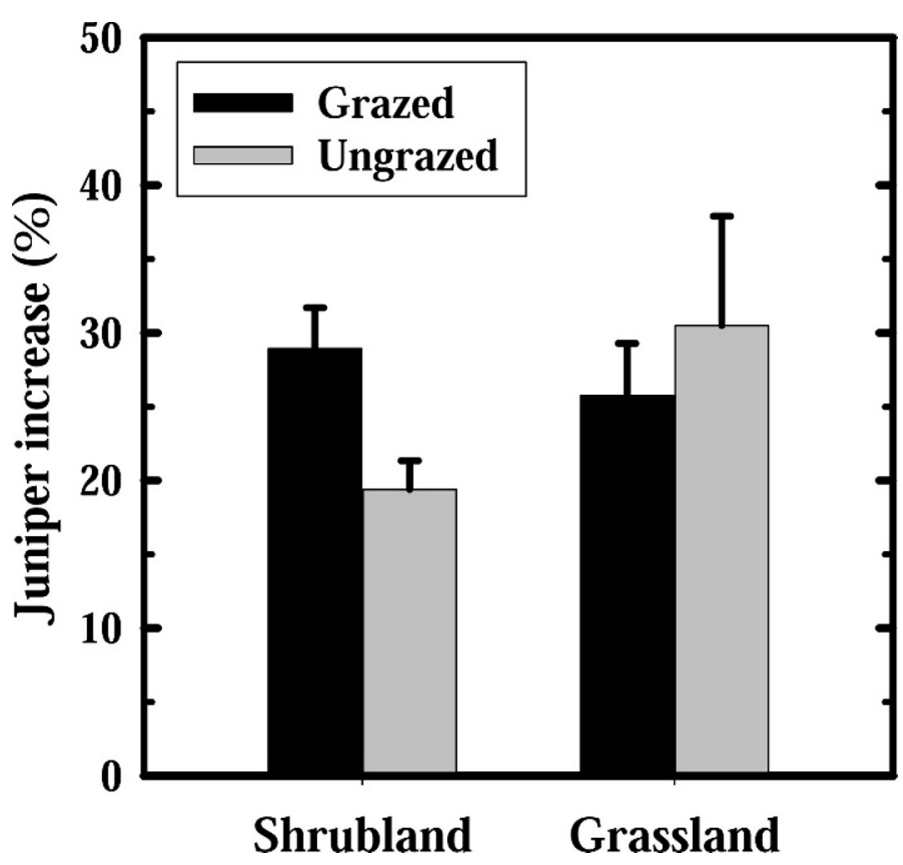

Figure 3. Mean $( \pm \mathrm{SE})$ increase in the percent of pixels with new juniper presence in grazed and ungrazed shrub land and grassland cover types between 1985 and 2005. $P=0.06$ for the interaction of grazing and cover type, $P<0.0001$ for the effect of grazing in grassland, and $P=0.06$ for the effect of grazing in shrub land. 

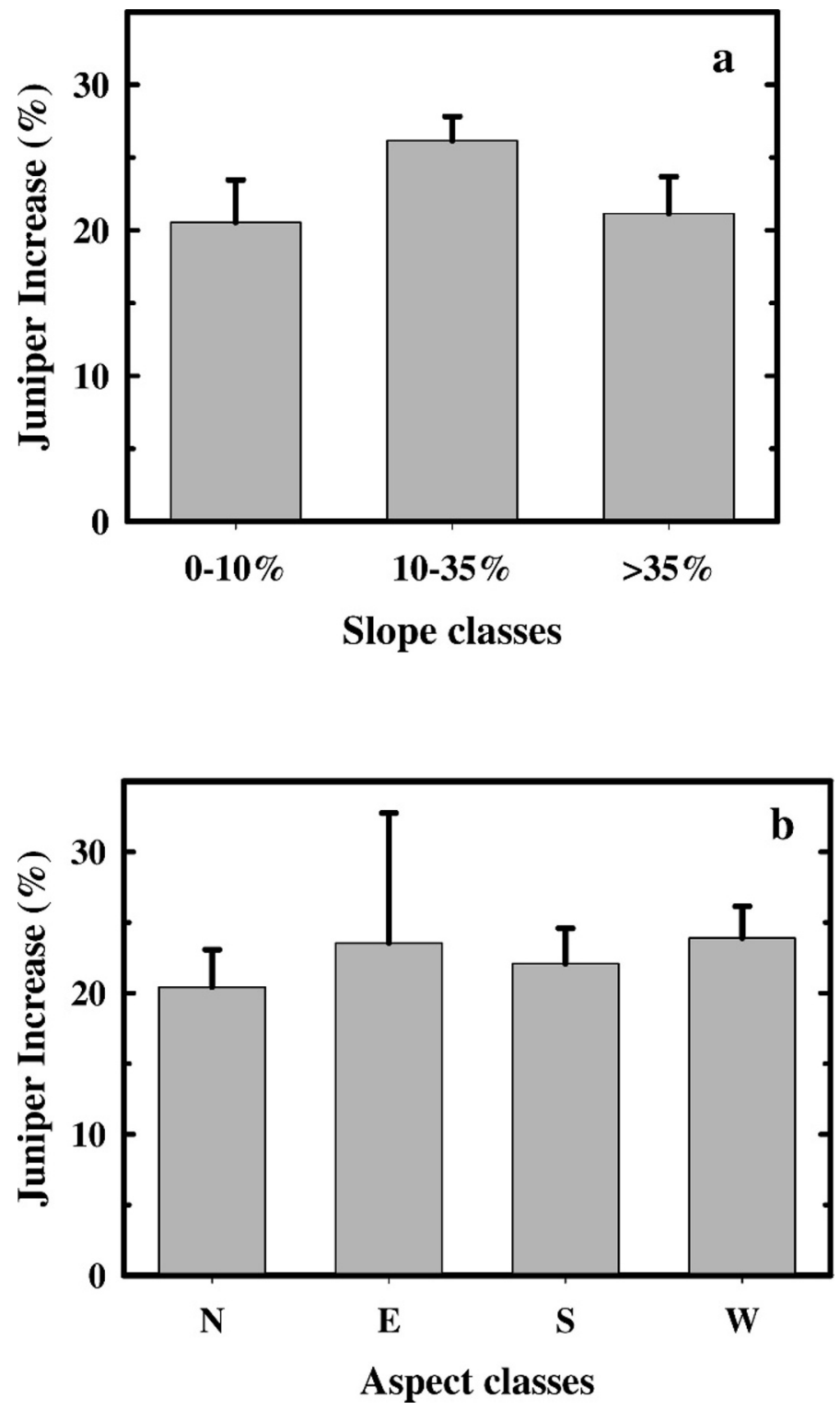

Figure 4. Mean $( \pm \mathrm{SE})$ increase in the percent of pixels with new juniper presence in categorical classes of slope (a) and aspect (b). $P=0.001$ for greater juniper increases on $10-35 \%$ compared to other slope class, $P=0.03$ for less juniper increase on northerly aspects and $P=0.02$ for more juniper increase on westerly compared to other aspects.

detection over the past $20 \mathrm{yr}$ for a large region of semiarid rangelands. However, the estimated temporal change in juniper cover is likely influenced by the lower classification accuracies in the 1985 image classification. The distinct spectral characteristics of pixels that had juniper, compared to pixels without juniper, were probably due to the dark greenness and relatively high leaf area of juniper compared to the surrounding lightcolored vegetation. These nonjuniper cover types had less foliage and chlorophyll during the dry end-of-growing season days from which we selected our imagery. Spectral properties associated with juniper in our particular study region, i.e., the juniper endmember, are not limited to its relatively dark green foliage but also include the unique shading, litter, soil exposure, and altered vegetation beneath or around junipers. Thus, we emphasize that the spectral profile for juniper endmember and especially background cover presented here likely would not transfer to other regions or times of year.

The results of this application have important implications for the monitoring and assessment of rapidly expanding juniper woodlands, which is an issue for over 24 million hectares in the western United States (Miller and Wigand 1994). Field-based approaches for detecting juniper cover changes provide highly accurate and valuable results, but they can be labor intensive, time consuming, and limited in the spatial extent they can cover. In comparison, the application of remote sensing methods can be more cost effective and timely due to the large areal extent they cover. Digital satellite imagery also provides opportunities for more robust and comprehensive analysis of change, as the imagery can be easily integrated with other sources of digital data, such as terrain models and digital maps of grazing boundaries or land cover types. Moreover, data from satellite platforms, such as Landsat, can be acquired in retrospect to examine past changes, in this case over 20 years.

Our results indicated up to $30 \%$ increase in pixels having juniper over the past $20 \mathrm{yr}$ in the Pocatello area of southeast Idaho. The estimated rates of increase in juniper cover in this study were in approximate agreement with the estimates of juniper increase in other areas based on different methods (Table 1). Notably, there appears to be more convergence of juniper change estimates from the large-scale studies. The estimated rate of juniper increase appeared different in our two regions, which might be due to the difference in the initial juniper cover between the two regions. The eastern region had a relatively greater increase in juniper cover and also greater initial juniper cover (approximately 25\%). Weisberg et al. (2007) indicate that juniper expansion rate can be densitydependent and the process might be dominated by infilling. Compared to other areas, they suggest that expansion rate might be greater in areas where the initial juniper cover is $>10 \%$. Our spatial pattern analysis indicated that juniper encroachment was randomly distributed in each region, and not locally clustered or uniform. The random spatial pattern might be associated with juniper dispersal systems that are facilitated by multiple factors including gravity, birds, frugivorous mammals, and some livestock that pass germinable seeds (Chambers et al. 1999). Padien and Lajtha (1992) also found juniper encroachment patterns to be random at regional scales.

Greater juniper encroachment in grazed compared to ungrazed areas in our study was consistent with the expected, but not often explicitly tested, positive effects of grazing on juniper increase suggested by previous studies (Miller and Wigand 1994; Miller and Rose 1995, 1999). Livestock grazing can decrease the competitive effects of palatable herbaceous species on new and establishing juniper trees (Evans 1988). The reduction in competition might accelerate juniper establishment (Johnsen 1962) by making plant communities more susceptible for juniper encroachment (Miller and Wigand 1994). Our findings of marginally greater juniper encroachment in grazed shrub land compared to ungrazed shrub land are also consistent with conclusions in previous literature. Livestock grazing can increase shrub species that help facilitate juniper encroachment (Gottfried 1992), and there are several ground-based reports affirming the encroachment of juniper into shrub steppe (Miller and Wigand 1994; Miller et al. 2000; 
Weisberg et al. 2007). Shrubs provide better soil moisture and protection from direct sunlight (Gottfried 1992; Miller and Rose 1995). Litter accumulation beneath shrub canopies further improves soil moisture and temperature, and provides nutrients to the developing juniper seedlings (Evans 1988).

Our results indicated that grazing and topographic positions were important predictor variables of juniper encroachment. Indeed, this model explained much of the variability in juniper encroachment without including land cover types as a predictor variable. This might indicate that topographic heterogeneity can be a more important factor than land cover types. Little is known regarding topographic effects on juniper encroachment (Johnson and Miller 2006; Weisberg et al. 2007). However, Johnson and Miller (2006) suggest that once a threshold is crossed in the juniper encroachment process, disturbances such as fire are no longer important and instead topography might become the important factor that explains much of the variability in juniper woodland expansion.

\section{MANAGEMENT IMPLICATIONS}

This study demonstrated a successful application of Landsat imagery and classification methods in detecting juniper cover increase. Juniper cover appears to be increasing in a random spatial pattern and at varying rates across the landscape due to differences in grazing use, land cover types, and topography. If further inquiry can demonstrate causality between juniper encroachment and these variables, land management can be adjusted to abate further unwanted increases in juniper. The approach described here could enable a more rapid assessment of juniper woodland changes across large areas and inform management decisions. An important feature of the approach is careful consideration of measurement conditions, so that spectral properties associated with juniper (e.g., dark green foliage, shadows, adjacent soil, and litter) strongly contrast background cover.

\section{LITERATURE CITED}

Adams, J. B., M. O. Smith, and P. E. Johnson. 1986. Spectral mixture modeling: a new analysis of rock and soil types at the Viking Lander 1 site. Journal of Geophysical Research 91:8098-8112.

Baker, W. L., and D. J. Shinneman. 2004. Fire and restoration of pinon-juniper woodlands in the western United States: a review. Forest Ecology and Management 189:1-21.

BILBRough, C. J., AND J. H. Richards. 1993. Growth of sagebrush and bitterbrush following simulated winter browsing: mechanisms of tolerance. Ecology 74:481-492.

Blackburn, W. H., and P. T. Tuelerer. 1970. Pinyon and juniper invasion in black sagebrush communities in east-central Nevada. Ecology 51:841-848.

Burkhardt, J. W., and E. W. Tisdale. 1976. Causes of juniper invasion in southwestern Idaho. Ecology 57:472-484.

Chambers, J. C., S. B. Vander Wall, and E. W. Schupp. 1999. Seed and seedling ecology of pinyon and juniper species in the pygmy woodlands of western North America. The Botanical Review 65:1-38.

Chavez, P. S., JR. 1996. Image-based corrections-revisited and improved. Photogrammetric Engineering and Remote Sensing 69:1025-1036.

Chen, X., L. Vierling, E. Rowell, and T. Defelice. 2004. Using lidar and effective LAI data to evaluate IKONOS and Landsat 7 ETM+ vegetation cover estimates in a ponderosa pine forest. Remote Sensing of Environment 91:14-26.
Evans, R. A. 1988. Management of pinyon-juniper woodlands. Washington, DC, USA: United States Department of Agriculture, Forest Service, Intermountain Research Station. General Technical Report INT-249. 34 p.

GotTfRIED, G. J. 1992. Ecology and management of the southwestern pinyonjuniper woodlands. In: P. F. Ffolliott, G. J. Gottfried, D. A. Bennett, V. M. Hernandez, C. A. Ortega-Rubio, and R. H. Hamre [TECH COORDS.]. Ecology and management of oak and associated woodlands: perspectives in the southwestern United States and northern Mexico. Washington, DC, USA: United States Department of Agriculture, Forest Service. p. 78-85.

JoHnSEN, T. N., JR. 1962. One-seed juniper invasion of Northern Arizona grasslands. Ecological Monographs 32:187-207.

Johnson, D. D., And R. F. Miller. 2006. Structure and development of expanding western juniper woodlands as influenced by two topographic variables. Forest Ecology and Management 229:7-15.

Kremer, R. G., and S. W. Running. 1993. Community type differentiation using NOAA/AVHRR data within a sagebrush-steppe ecosystem. Remote Sensing of Environment 46:311-318.

LillesAnd, T. M., And R. W. KiefER. 2000. Remote sensing and image interpretation. 4th ed. New York, NY, USA: Wiley. $568 \mathrm{p}$.

Mlller, R. F., And J. A. Rose. 1995. Historic expansion of Juniperus occidentalis (western juniper) in southeastern Oregon. Great Basin Naturalist 55:37-45.

MILleR, R. F., AND J. A. Rose. 1999. Fire history and western juniper encroachment in sagebrush steppe. Journal of Range Management 52:550-559.

Miller, R. F., T. J. Svejcar, and J. A. Rose. 2000. Impacts of western juniper on plant community composition and structure. Journal of Range Management 53:574-585

Miller, R. F., And P. E. Wigand. 1994. Holocene changes in semiarid pinyon-juniper woodlands. Bioscience 44:465-473.

O'Sullivan, D., And D. Unwin. 2003. Geographic information analysis. New York, NY, USA: Wiley. p. 197-201.

Padien, D. J., and K. Lajtha. 1992. Plant spatial pattern and nutrient distribution in pinyon-juniper woodlands along an elevational gradient in northern New Mexico. International Journal of Plant Sciences 153:425-433.

Ratzlaff, T. D., and J. E. Anderson. 1995. Vegetal recovery following wildfire in seeded and unseeded sagebrush steppe. Journal of Range Management 48:386-391.

Rencz, A. N. 1999. Remote sensing for the earth sciences. New York, NY, USA: Wiley. p. 251-307.

Small, C. 2004. The Landsat ETM+ spectral mixing space. Remote Sensing of Environment 93:1-17.

Small, C., and J. W. T. Lu. 2006. Estimation and vicarious validation of urban vegetation abundance by spectral mixture analysis. Remote Sensing of Environment 100:441-456.

Strand, E. K., A. M. S. Smith, S. C. Bunting, L. A. Vierling, D. B. Hann, and P. E. Gessler. 2006. Wavelet estimation of plant spatial patterns in multitemporal aerial photography. International Journal of Remote Sensing 27:2049-2054.

uS Department of Agriculture National Agricultural Imagery Program. 2004. Available at: http://giscenter.isu.edu/data. Accessed 15 May 2006.

us Department of Agriculture Natural Resources Conservation Service. 1997. Soil survey geographic (SSURG0) database for St. Joe Area, Idaho. Fort Worth, TX, USA: USDA.

Waichler, W. S., R. Mlller, and P. S. Doescher. 2001. Community characteristics of old-growth western juniper woodlands. Journal of Range Management 54:518-527.

Wall, T. G., R. F. Miller, and T. J. Svejcar. 2001. Juniper encroachment into aspen in the Northwest Great Basin. Journal of Range Management 54:691-698.

Weber, K., and BLM Pocatello Field Office. 2006. The spatial database. Available at: http://giscenter.isu.edu/data. Accessed 15 October 2006.

Weisberg, P. J., E. Lingua, And R. B. Pillai. 2007. Spatial patterns of pinyon-juniper woodland expansion in central Nevada. Rangeland Ecology and Management 60:115-124.

XIAO, J., AND A. Moody. 2005. A comparison of methods for estimating fractional green vegetation cover within a desert-to-upland transition zone in central New Mexico, USA. Remote Sensing of Environment 98:237-250. 